\title{
TRANSPOSITION
}

\section{OF DRUPADI IN GARIN}

NUGROHO'S SETAN JAWA:

WOMAN AS A JAVANESE

SYMBOLIC ACT

\author{
\begin{tabular}{l|l} 
Agustina Kusuma Dewi & Faculty of Art and Design $^{1}$
\end{tabular} \\ Yasraf Amir Piliang Bandung Institute of Technology \\ Irfansyah \\ Bandung, Indonesia
}

Acep Iwan Saidi

\begin{abstract}
:
Art film is a film full of symbols. The film Setan Jawa by Garin Nugroho (2016) brings the concept of a silent film and the cinematic-orchestral collaboration with various standards across arts, while also adapts some cultural narratives in the Javanese context. This film presents Drupadi narrative, one of the Javanese Wayang cultural narratives. Drupadi is often referred to as a symbol of women's loyalty and obedience to the universal law, through her obedience to her husband and mother, although this obedience is contrary to the self (I) concept. With the help of textual analysis, this article aims to identify the adaptation of Drupadi's cultural narrative that is creatively transposed in the film Setan Jawa. The results show that there is a director's personal code (idiolect) in the film, that offers women' representation different from the conventions in the Javanese culture. While the conclusion might be arguable, one can reflect on the symbolic act of women's representation being creatively transposed not as subordinate but as having the power to fulfill their own destiny.
\end{abstract}

Keywords:

idiolect $\bullet$ sociolect $\bullet$ creative transposition - women's representation $\bullet$ self $\bullet$ art film 


\section{Introduction}

The current development of film industry is in line with the advances in film technology that bring impact in changing the status and role of film. Film, which was born as a public spectacle (early 1900's), was an alternative to big business entertainment services in the future of urban people and was labeled as "low entertainment" for the urbanites. Film is then considered to be capable of penetrating all levels of society, including the middle and the upper layers, as well as the intellectual and the cultural layers. Resistance films emerged and wanted to escape from the uniform face of Hollywood, which then gave birth to Auteur films, namely the directors' personal films, that are often referred to as art films. ${ }^{2}$

Referring to film scholar David Bordwell's statement in a 1979 article entitled "The Art Cinema as a Mode of Film Practice", art films are those that dare to infuse their narrative with two principles: realism and authorial expressiveness using the play of symbols. Art films often "have a distinctive visual style" of the writer and / or the director, and because of these characteristics, as Bordwell claims, art cinema (film) itself is a genre with different conventions. ${ }^{3}$

Silent films, such as those exemplified by films by Méliès and Griffith, were a form of art film that was still being produced until 1936. However, after the invention of sound production technology that had the ability to synchronize music and voice to celluloid in 1929, music quickly became an integral aspect of storytelling process, and composers were commissioned by the Hollywood to write new compositions, especially for films. Silent films became an art form that people abandoned for practical purposes. Some examples of silent films in black and white that became an inspiration for filmmakers include Metropolis (Fritz Lang, 1927), Wings (William A. Wellman, 1927), Modern Times (Charlie Chaplin, 1936), and The Artist (Michael Hazanavicius, 2011).

In 1990, with the presence of cinema advertisements that have been published in newspapers, Indonesian films have grown and developed 
toward the emergence of various films with various themes. Apart from commercial films that target the industry, including Kuldesak (Nan Achnas, Mira Lesmana, Riri Riza, Rizal Mantovani, 1998) and Ada Apa Dengan Cinta? (Rudi Soedjarwo, 2002) in those years, there were also noncommercial films that place a greater emphasis on the play of symbols, like Pasir Berbisike (Nan Achnas, 2001) and Daun di Atas Bantal (Garin Nugroho, 2008), which have won many awards. The later were born of an auteur, a film director who exercises highly centralized and subjective control over the many aspects of a collaborative and creative work. The term 'auteur' usually refers to a film-maker ${ }^{4}$ or a director with a distinctive style or thematic preoccupations. ${ }^{5}$ One of the auteurs is Garin Nugroho. ${ }^{6}$ Garin Nugroho is considered a film director who has visual aesthetics that is different from other Indonesian film-directors, and who applies cinematic techniques in his films. ${ }^{7}$

Setan Jawa is the first black-and-white silent film directed by Garin Nugroho. Presenting the same aura as when the first appearance of inaudible film, which is more familiar with the term silent film in the 'Silent Era' (1890s to 1929), this is a film which music is performed directly by musicians. Through the Setan Jawa film, Garin Nugroho tries to re-explore the history of silent films as an important moment in the birth of cinema. The release of the black-and-white silent film Setan Jawa in Jakarta in September 2016 at the Jakarta Theater Building was its first appearance before it was screened at the world premiere at the Opening Night of Asia Pacific Triennial of Performing Arts in Melbourne, February 2017. Based on an interview with Garin Nugroho (2019), the film Setan Jawa (see documentation on Figure 1) raises the grand narrative of the colonial era in the early $20^{\text {th }}$ century in Java, which in Garin's view was an era of industrialism development accompanied with infrastructure development, the growth of the nationalist movement, and Javanese human identity which was represented in everyday life, art, language and mystics. In this era, as theosophy grew, Javanese mysticism developed into a religious movement based on the harmony of various religious perspectives. In this regard, Garin Nugroho (2018) also reveals that the historical frame of 
the early $20^{\text {th }}$ century as the concept of time in Setan Jawa is an interesting aspect to explore and it allows the diachronic events to shape the expression of this film, moving between tradition and contemporary and in various cross-disciplines of art and culture. ${ }^{8}$

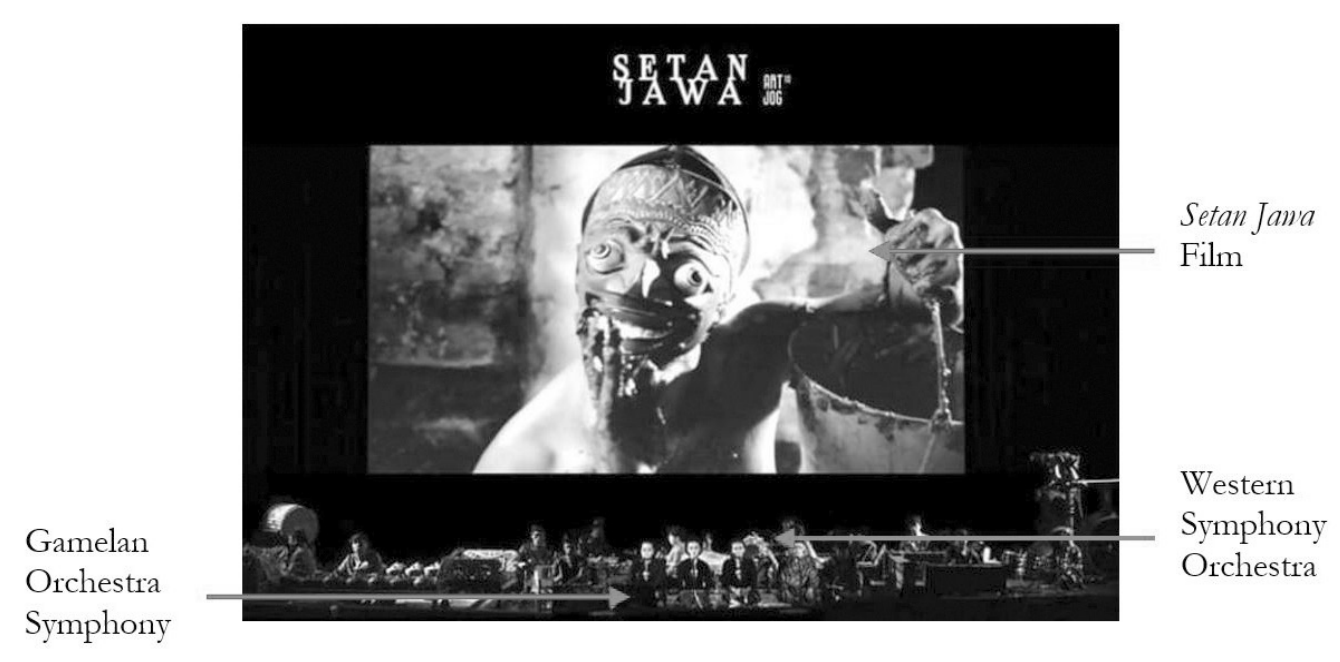

Figure 1. Documentation of Setan Jawa Sine-Orchestra Film Show ${ }^{9}$

Setan Jawa film is supported by a cinematic-orchestral approach, which in cultural communication can act as a medium for cultural discussion. ${ }^{10}$ Until recently (2020), this film has been scheduled to tour the world and has received positive appreciations in the country where it is shown and is regarded a medium of cultural discourse as well as a work of silent film. In the words of Iain Grandage, one of the Australians composers who have been involved in the orchestral process of filming Setan Jawa, "... with a cinematic-orchestral approach, [it] has the potential to create spaces for inter-cultural collaboration." 11

Being different from the standards of conventional film theory, Garin Nugroho's Setan Jawa deserves to be called an art film, for in addition to offering an alternative form in cinematography built up by the variety of arts, it also reveals the director's expressiveness in his relationship with Javanese cultural values represented through the various symbols in the 
film. In collaboration with composer Rahayu Supanggah, the screening of the film involves a musical performance that goes hand in hand with every second of the film's duration on stage. The screening of the film, as expressed in response to the audience's perceptions, "became an event that seemed hard to forget." 12

In an interview, Garin Nugroho (2020) admits that the Setan Jawa took inspiration from the film Nosferatu (1922) by Friedrich Wilhelm Murnau and Metropolis (1972) by Fritz Lang and the traditional form of shadow puppet shows. The inspiration for the puppet can be seen on the formation of the stage arrangement in this film. This form of performance is the 'language' of Garin Nugroho as the director, to convey the roots of the Indonesian cultures, which in this case Javanese culture, to the world community. He says, "We can only convey our (Indonesian) culture if we speak in a language that the international world understands. Advances in technology, globalization, now require such things" (Interview with Garin Nugroho, 2019). Because this film is a silent film, various nonverbal signs, that is, messages that do not use spoken language (words) in the form of metacommunication (messages behind messages) in films, ${ }^{13}$ are constructed as symbolic actions that are ambiguous, abstract, and arbitrary. ${ }^{14}$

In the film Setan Jawa, mysticism, according to Garin Nugroho, "becomes a form of multicultural identity that can be communicated to various parts of the world; even further, it has the potential to build different forms of collaboration without losing cultural roots." In this case, what happens is the exchange and expansion of culture (".. adding various perspectives, and create an ever bigger exchange....”.). ${ }^{15}$ This assumption also suggests that the semiological process occuring in Setan Jawa is very likely to produce meaning with broad modifications, as a creative translation and/or transposition of cultural narratives in films, into a symbol system which, with prior agreement between source and destination, is used to represent and convey information; or is a system of rules given by the culture, a code. Here, the medium, or means of adaptation that puts the source language into a new context for a specific purpose, involves a process of intersemiosis which refers to a one-way metalingual operation, in which linguistic signs (said Gorlee, 2008) ${ }^{16}$ are creatively reshaped or transformed into nonlinguistic elements and codes. 


\section{Method}

This qualitative research uses textual analysis to interpret cultural narrative adaptation in Setan Jawa film. Here, "symbolic interpretivism" method was used by focusing on communication media in art and design, showing a collection of signs and iconics, and bringing forward some relations of meaning that can be interpreted freely by the audience/ readers. The data collected in this study is referential data and visual data, which includes referential data of Garin Nugroho's work and Drupadi cultural narrative text, while the visual data are obtained from the selected frames of Setan Jawa film. The film is a creative transposition, asymmetric intersemiosis' process. With a duration of one hour twelve minutes and thirty seconds, the film is divided into seven chapters consisting of 4350 frames in telling a story of love and human tragedy set in the early $20^{\text {th }}$ century. 'Setyo' (Heru Purwanto), a young man from a poor village, falls in love with 'Asih' (Asmara Abigail), a daughter of a Javanese nobleman. Rejection made Setyo seek luck by dealing with a wealth-demon (the socalled "Setan Jawa", performed by Luluk Ari), also known as "Pesugihan Kandang Bubrah", to seek wealth and that later he might be able to propose Asih. Setyo eventually became rich and married Asih, they lived happily in a magnificent Javanese house. It wass only later that Asih found out that her husband was practicing "Pesugihan Kandang Bubrah".

Asih, who loves her husband very much, then meets the pesugiban devil, represented in the film by Setan Jawa. Garin Nugroho presents the devil in the film Setan Jawa as a concrete form of emotional transition to anger represented by the characterization of a young child (Muhammad Fathan Irsyad, as "Setan Jawa Kecil") who, when imprisoned by the Dutch, experienced physical and mental torture due to his actions of defending himself. Asih sacrifices herself to the demon so that her husband will not die as pillar of the house. Asih's sacrifice in the film Setan Jawa positions her to be the female protagonist character. She did not attempt to avoid the destiny that was caused by her husband's practice of seeking wealth by dealing with the demon. 
In Setan Jawa, various visual forms are developed by exploring Javanese mysticism, combining traditional Javanese with modern concepts. It becomes a free game of the creator's personal code and marker, which is the creator's personal language of expression and speech style. Motion as a sign that represents Javanese human identity in this film is thickly implemented in a variety of collaborative creative transpositions of cultural narrative gestural behavior of the characters (performers), as an effort to translate Javanese cultural identity in everyday life.

\section{Results}

Creative Transposition Process of Women's Representation in Films: Director's Idiolect versus Sociolect

\section{Drupadi narrative: Game of Dice Gambling}

In the Mahabharata, Drupadi obeyed when Yudhisthira said that she would become the common wife of also Bima, Arjuna, Nakula, and Sadewa. The reason is because they are siblings, difficult to be together, and happy to be together. Her marriage to the Five Pandavas, took place after the Pandavas visited the Pancala Kingdom and Arjuna won the Wisdom archery competition. Not long after marrying Drupadi, the Pandavas' life began to improve. Yudhistira was crowned king in Indraprastha. The cunning Sengkuni also plans to have a dice match with Yudistira. At that time, the game of dice was an elite game among royal aristocrats. Yudhisthira lost, Drupadi was made the last bet when the kingdom, property, and his siblings were seized. Feeling that Drupadi had become his property, Dursasana tried to expose her in public. But it happened that the layer of the Drupadi shawl seemed never to run out when Dursasana tried to take it off. Still, Drupadi was ashamed to ask for forgiveness. She remained obedient, did not fight back, only Bima then defended his honor, although it did not matter, because he too had become an item at stake. 


\begin{tabular}{|c|c|}
\hline Mahabharata Version (India) & The Purwa Wayang Kulit version \\
\hline $\begin{array}{l}\text { Drupadi is not in the spotlight, } \\
\text { but is portrayed in the historical } \\
\text { narrative, a female protagonist } \\
\text { in the struggle against the } \\
\text { Kauravas. She gave up her body } \\
\text { for the sake of Indraprastha's } \\
\text { integrity. Her love for science } \\
\text { and politics, her fortitude when } \\
\text { faced with the reality of having } \\
\text { to marry the five Pandavas. She } \\
\text { did polyandry that she didn't } \\
\text { want, but she had to obey } \\
\text { the traditions and laws of the } \\
\text { mother, Kunti, at that time. }\end{array}$ & $\begin{array}{l}\text { Drupadi in the Javanese puppetry } \\
\text { is narrated as a loyal companion of } \\
\text { Yudistira. The same narrative can } \\
\text { also be found in puppet stories, } \\
\text { namely the wife of Puntadewa or } \\
\text { Yudistira (Peter Carey, Vincent } \\
\text { Houben, 2016: 5), she undergoes } \\
\text { monogamy. The story of Drupadi } \\
\text { has been polished. The famous } \\
\text { poet Rangga Warsita through } \\
\text { Serat Pustaka Raja Purwa narrates } \\
\text { Drupadi as Yudistira's wife with } \\
\text { a different contest story. In the } \\
\text { Javanese puppetry, she is a symbol } \\
\text { of a wife's loyalty to her husband. } \\
\text { Drupadi's obedience to Yudistira } \\
\text { accompanied the whole journey of } \\
\text { joy and sorrow until the end of her } \\
\text { life. Drupadi's loyalty is considered } \\
\text { to be an example for every woman. }\end{array}$ \\
\hline
\end{tabular}

Cultural studies tends to look at the world and the interactions between the elements in it as constituting a textual construction that is intertwined with one another. The concept of text does not only refer to written words, but also covers various interpreting practices represented by other elements in the form of images, sounds, objects, and activities. Because all of these elements are also within a signalling system, the mechanism of action resembles language so that they can be considered cultural texts. The understanding of cultural texts that can differ between creators and audiences results from the articulation process marked by the formation of new codes and requires deepening of meanings. The code as a rule agreed upon by members of the community needs to be approached in the cultural context. This is because the problems of representation and identity as cultural studies often lead to social and cultural differences, 
due to the diversity of media used as styles of expression in a cultural communication process. In the process of sign articulation, it is possible to expand the meaning of the sign (overcoding) ${ }^{17}$ and the formation of personal $\operatorname{codes}^{18}$ (idiolek, idiolect).

Umberto Eco argues that message interpretation demands continuous additional coding, namely by challenging and hypothetically modifying the existing codes. One of the additional coding modes in text interpretation is overcoding (excessive coding), which is an extension of the additional meaning given to a certain series of small expressions. ${ }^{19}$ The extension of this additional meaning will depend heavily on expressions which lead to a situation of "deviation from general norms" and the existing sociocultural codes. This allows the formation of a "new code" which is only spoken by one speaker and understood by a very limited audience. It is a kind of "private code" which is equivalent to 'sinsign' (singular sign), namely a sign that is singular, and not a general sign, which can only be understood personally. ${ }^{20}$ The limited general understanding of the "new code" has the opportunity to give rise to 'Idiolek' (Idiolect) which is defined as "individual patterns or styles", a radical code making process that involves code changing resulting in an original sign function. ${ }^{21}$

In connection to the personal code mentioned above, the creative transposition of cultural narratives in Setan Jawa film concerning 'Pesugihan' which can be broken only by giving up one's life, is creatively transposed by Garin through Drupadi's narrative, which is not positioned according to the standards of the story. The transposition of Drupadis cultural narrative represented as a female figure with obedience to the destiny of the universe is shown through the concept of visuality, showing a structured gender hierarchy, its relation to the relationship between cinema and visual enjoyment. The female body in the film ('Asih', by Asmara Abigail) is constructed by taking certain pictures, sometimes different from the patterns of depicting persons in the film. 


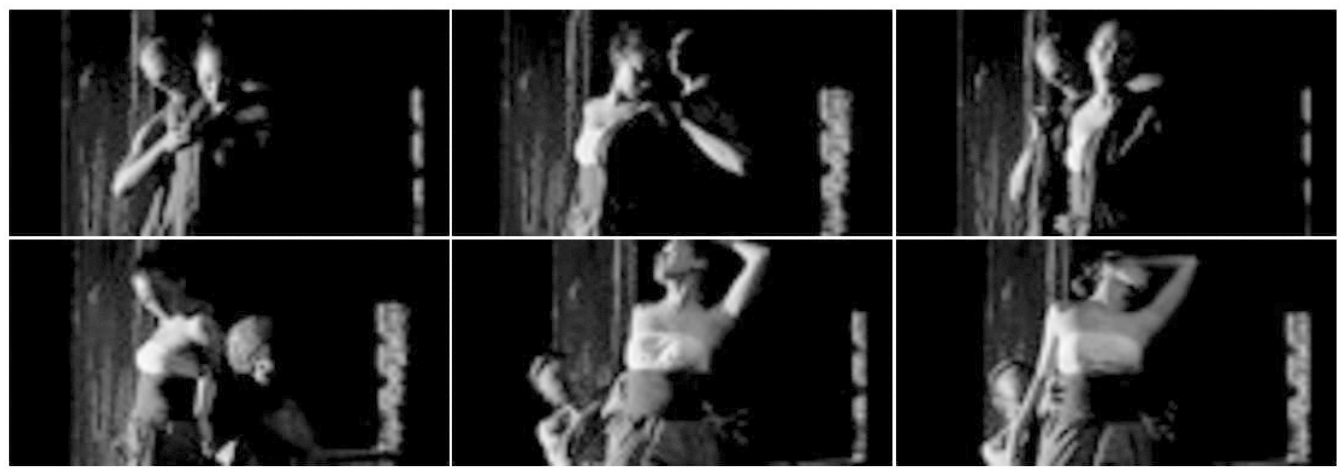

Figure 2. Drupadi's creative narrative transposition, representing women in visuality, but different from the convention of women's representation in Javanese cultural identity (Source: Documentation of the film Setan Jawa, Australia-London, Garin Workshop, 2017)

In contrast to Drupadi, which in the original text of Wayang Kulit Purwa (Javanese) version is depicted as a character who does not intentionally show her beauty, in Setan Jawa film, Asih is mostly displayed through a visual code with strong erotic impact, aimed at attracting the audience to feel the same desires perceived by other characters in the film. In the beginning, Asih's surrender to "Setan Jawa" in order to ask forgiveness for her husband emphasizes the idea of her physical position as male's sexual object, resulting in a process of mental representation (conceptual map) that confirms a patriarchal culture and male domination over women (Figure 1).

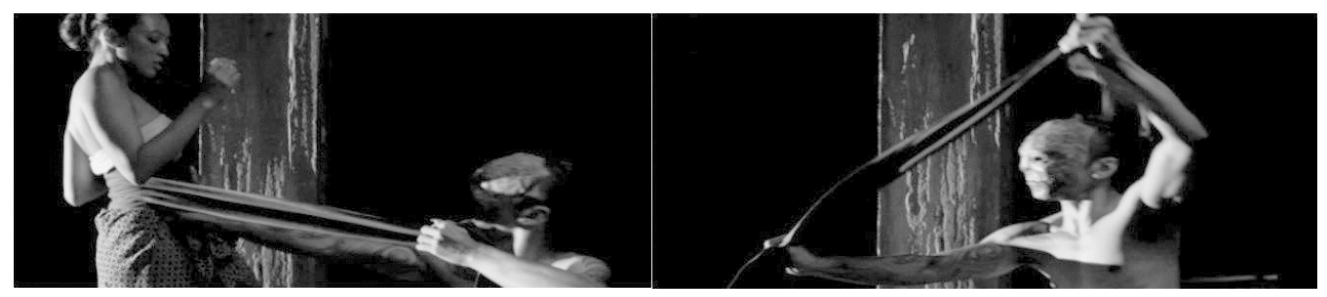

Figure 3. Asih's gesture of rejection when her shawl was loosened (Source: Documentation of the film Setan Jawa, Australia-London, Garin Workshop, 2017)

The scene when the character "Setan Jawa" loosens Asih's shawl (Figure 2) wants to adapt the Drupadi narrative with an extension to the 
original Mahabharata (India) and "Wayang Purwa" versions, although in this scene Asih's gesture of rejection brings a different meaning to the female representation in Drupadi's narrative and her obedience. In Figure 2 , women are no longer represented as merely a sign of a sex object in films, but are able take control of their own choices.

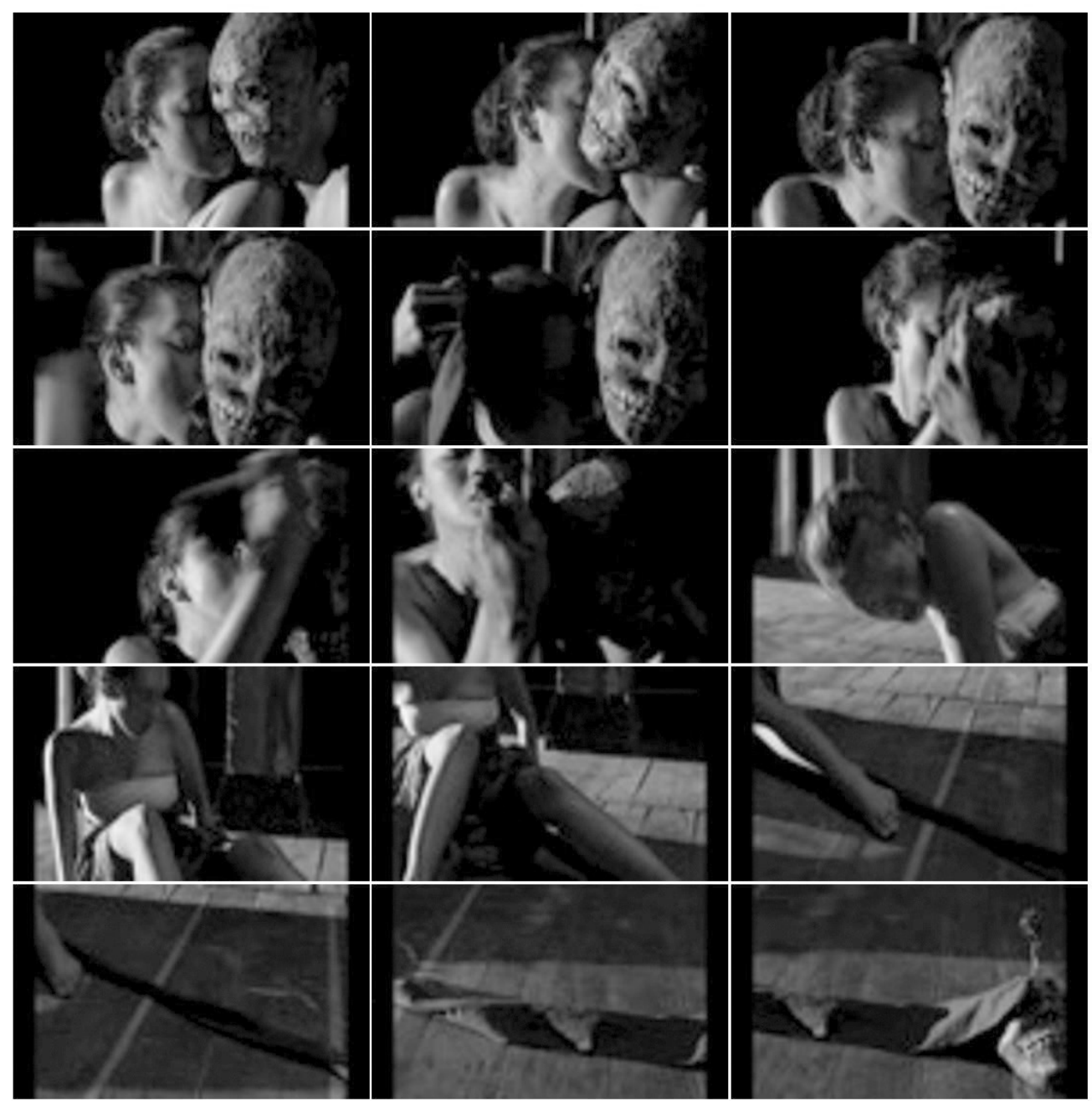

Figure 4. A different way of representing women's autonomy in symbolic acts formed by creative transpositions in the film Setan Jawa. (Source: Documentation of the film Setan Jawa Australia-London performance, Garin Workshop, 2017) 
The representation of women in Setan Jawa is no longer subject to the convention of cultural narratives regarding the cultural identity of Javanese women, while maintaining strong gestures and without losing the characters of flexibility and full confidence. In Setan Jawa film, Javanese women are described as 'heroines' in the imaginary meaning of the term and not merely as object of sexual fantasy and satisfaction. Here one can find a reversal gaze that identifies women as having complete autonomy over themselves, and even over their own destiny. On the contrary, a man can lose his bodily strength when confronted with destiny, that in this film is depicted with Setyo's helplessness in facing the consequences of "Pesugihan Kandang Bubrah".

\section{Discussion}

The transposition in this film creatively provides a different perspective on the meaning of Drupadi narrative from the point of view of the director's ideology. There is an expansion of the meaning of both the Drupadi narrative in the Mahabharata (India) and the Drupadi narrative in the Javanese cultural context, explained as follows.

1) Asih's surrender to Setan Jawa is a representation of the heroic attitude of a woman who takes part in the conflict situation she is facing, which is actually a conflict situation due to the actions of Setyo, her husband. Asih's symbolic act was similar to Drupadi's obedience, shown when Kunti required him to marry Pandawa Lima, as well as Drupadi's obedience as wager in dice gambling. This transposition adapts the Drupadi narrative from India, but what distinguishes it from the two versions of Drupadi is that in this scene Asih is depicted as showing sensuality in the small gestures of her body.

2) Garin's idiolect was raised by transposing the merging of the Mahabarata (Indian) version of the Drupadi narrative and the "Wayang Purwa" version, although not on the form layer, but on the thematic layer. This is shown with several symbolic acts in the scenes in Figure 2, Figure 3 and Figure 4, as follows. [1] 
On the surface, Asih surrenders her body to Setan Jawa. This is a transposition of the Drupadi Narrative in the Mahabarata. But on the thematic layer, Asih's surrender is a representation of women in the Javanese cultural context as constructed in the "Wayang Purwa" version of the Drupadi narrative. Asih's symbolic act shows loyalty and sacrifice to her husband, Yudistira. [2] Asih surrenders to Setyo, who has allied himself with Setan Jawa, and therefore connotatively also shares wife with Setan Jawa. This is consistent to the narrative in the Mahabharata, and related to women's polyandry. However, on the thematic level, Garin again returns the meanings of sacrifice and polyandry to the contexts of loyalty and monogamy, and that Asih's symbolic act is considered a form of resistance to destiny. This is beyond the boundaries of women's ethics and philosophy in the Javanese culture. This is a representation of the heroism of Javanese women, who have always been associated with the perception that Javanese women are helpless, obedient, and considered as a "friend to sleep" (kancawingking). ${ }^{22}$

3) The chaos of symbolic acts in Garin's creative transposition has the potential to construct his idiolect as a pattern of adaptation of the original text to certain cultural contexts which are mediumconverted into films.

Referring to a social behaviorist, G.H. Mead, one can argue that human behavior in a social context presents a personal self which includes two components of "I" and "Me". The creative transposition of the Drupadi cultural narrative in Setan Jawa shows the separate elements of individuality, that is, "I' as persona and "Me" as an element that participates in the social context. As a representation of female protagonist in the film, Asih is presented through an intersemiotic transposition, which in the archetype of a cultural framework presents the three dimensions of "Me": ontological, functional, mythic. ${ }^{23}$

A mythic culture is a manifestation of The-Self, that is, "Me" who is still fused with power and threats into the environment; "I am Ontologically" who is able to distance My-Self (The I) from the forces in the environment, 
to realize mine-self as separate and to research, explore the environment; "I am Functionally" is aware of the relationship with the environment and expressing My-Self through this connection, carrying out a function in the relationship. "I am" as "The-I" is taking part in the happenings around and merging with the forces of nature into a participation. External powers can pass through to "Me", while miraculous powers are found through various symbols in myths. The negative dimension takes the form of a magical attitude, while the positive dimension of a religious attitude. ${ }^{24}$

\section{Conclusion}

The film Setan Jawa seems to try to offer formation and interpretation of public discourse about an adaptation based on intersemiotic texts and different cultural narratives. It does so by presenting other constructs related to the reality of seeing-and-being seen, between the self and others, between those who are controlled-and-controlling in the representation of women as protagonists in the figure of Asih. One can find the director's idiolect (idiolek; personal code) in the film, while seeing also a clash with sociolect (sosiolek; conventionalized code) passed down from generation to generation in the Javanese cultural context.

\section{References:}

Barker, Chris. Cultural Studies: Teori \& Praktik. Terj. Nurhadi. Ed. Hadi Purwanto. Judul asli: Cultural Studies: Theory and Practice. Yogyakarta: Kreasi Wacana, 2011.

Belasunda, Riksa, et. al. "Medium Hybridity in the Javanese Opera Film by Garin Nugroho as a Deconstruction”. ITB J. Vis. Art \& Des, Vol. 6, No. 2 (January 2014).

Bordwell, David, Kristin Thompson, Jeff Smith. Film Art: An Introduction. $11^{\text {th }}$ Edition. New York: The McGraw-Hill Companies, 2017.

Budiman, Christian, Irwan Abdullah, and G. R. Lono Simatupang, "Opera Jawa [Requiem from Java]: A Semiotic Narratology Perspective", in journal K@ta (2015): 33-38 (DOI: 10.9744/kata.15.1.33-38).

Caughie, John. Theories of Authorship. New York: Routledge \& Kegan Paul Ltd, 1981. 
Danesi, Marcel. Messages, Signs, and Meanings: A Basic Book in Semiotics and Communication Theory. Toronto: Canadian Scholar's Press, 2004.

Dewi, Agustina K., Yasraf Amir Piliang, Irfansyah, and Acep Iwan Saidi, "Film Sinematik-Orkestra sebagai Media Komunikasi Budaya (Studi Kasus 'Setan Jawa' Karya Garin Nugroho)". Proceedings from Seminar Internasional Riksa Bahasa (May 2020).

Eco, Umberto. Teori Semiotika: Signifikasi Komunikasi, Teori Kode, serta Teori

Produksi Tanda. Terj. Inyiak Ridwan Muzir. Judul asli: A Theory of Semiotics. Yogyakarta: Kreasi Wacana, 2009.

Ewata, Thompson. "Meaning and Nonverbal Communication in Films", Issues in Language \& Linguistic: Perspectives from Nigeria, Vol. 3 (June, 2016).

Hall, Edward T. Beyond Culture. New York: Anchor Book, 1976.

Hall, Stuart. "The Question of Cultural Identity" in S. Hall, D. Held, \& T.

McGrew (Eds.), Modernity and Its Futures (Cambridge: Polity Press, 1992): 277-280.

Herusatoto, Budiono. Simbolisme Jawa. Yogyakarta: Penerbit Ombak, 2008. Noerhadi, Tati H. I Am in Culture: A Philosophical Study of the Relationship of Subject Objects. Jakarta: PT Dunia Pustaka Jaya, 1984.

Peter Carey and Vincent Houben, Perempuan-Perempuan Perkasa di Jawa Abad XVIII-XIX, Cetakan Ketiga. Jakarta: Kepustakaan Populer Gramedia, 2018.

Piliang, Yasraf Amir. Medan Kreativitas: Memahami Dunia Ide. Yogyakarta: Cantrik Pustaka, 2019.

Sudibyoprono, R. Rio., Danisworo, Mujiyono, Suwandono. Ensiklopedi Wayang Purwa. Jakarta: Balai Pustaka, 1991.

Wood, Julia T. Communication Theories in Action: An Introduction. $3^{\text {rd }}$ Edition. Belmont, Calif.; London: Wadsworth, 2003.

Wu, E-Chou. "Intersemiotic Translation and Film Adaptation". Providence Forum: Language and Humanities, Vol. VIII, No.1 (December 2014).

\section{Endnotes:}

1 Postgraduate student at Faculty of Art and Design, Bandung Institute of Technology, Bandung, Indonesia; email: agustinakusumadewi.3881@gmail.com.

2 David Bordwell, et. al., Film Art: An Introduction, 11 ${ }^{\text {th }}$ Edition (New York: The McGraw-Hill Companies, 2017) 53. 
3 Ibid., 55.

4 Further references about Auteur Theory can be seen in John Caughie, Theories of Authorship (New York: Routledge \& Kegan Paul Ltd, 1981).

5 Bordwell, et. al., op. cit., 53-55; see John Caughie, Theories of Authorship, ibid.

6 Christian Budiman, Irwan Abdullah, and G. R. Lono Simatupang, "Opera Jawa [Requiem from Java]: A Semiotic Narratology Perspective”, in Journal K@ta (2015): 33.

$7 \quad$ Ibid., 34.

8 Interview with Garin Nugroho with The Jakarta Post, https://www.thejakartapost. com/life/2018/10/12/setan-jawa-a-celebration-of-image-and-sound.html (access 23.04.2019).

9 From www.facebook.com/setanjawamovie (access 29.05.2019).

10 Agustina Kusuma Dewi, Yasraf Amir Piliang, Irfansyah, and Acep Iwan Saidi, "Film Sinematik-Orkestra sebagai Media Komunikasi Budaya (Studi Kasus 'Setan Jawa' Karya Garin Nugroho)", in Proceedings from Seminar Internasional Riksa Bahasa (May 2020): 1607-1612.

11 Interview with Iain Grandage in The Jakarta Post, https://www.thejakartapost. com/life/2018/10/12/setan-jawa-a-celebration-of-image-and-sound.html (access 23.04.2019).

12 Documentation of Setan Jawa, from https://twitter.com/jaffjogja/ status/1043870929296584704 (access 23.05.2019).

13 Thompson Ewata, "Meaning and Nonverbal Communication in Films", in Issues in Language \& Linguistic: Perspectives from Nigeria, Vol. 3 (June, 2016): 93-95.

14 Julia T. Wood, Communication Theories in Action: An Introduction, $3^{\text {td }}$ Edition (Belmont, Calif.; London: Wadsworth, 2003) 87.

15 Interview with Garin Nugroho, 2019, and Garin Nugroho's Interview in The Jakarta Post, from https://www.thejakartapost.com/life/2018/10/12/setan-jawa-acelebration-of-image-and-sound.html (access 23.04.2019).

16 E-Chou Wu, "Intersemiotic Translation and Film Adaptation", in Providence Forum: Language and Humanities, Vol. VIII, No.1 (December 2014): 149-182.

17 Yasraf Amir Piliang, Medan Kreativitas: Memahami Dunia Ide (Yogyakarta: Cantrik Pustaka, 2019) 235.

18 Ibid.

19 Ibid.

20 Ibid.

21 Ibid., 237.

22 Peter Carey, Vincent Houben, Perempuan-Perempuan Perkasa di Jawa Abad XVIIIXIX, Cetakan Ketiga. (Jakarta: Kepustakaan Populer Gramedia, 2018) 5-7.

23 Tati H. Noerhadi, I Am in Culture: A Philosophical Study of the Relationship of Subject Objects (Jakarta: PT Dunia Pustaka Jaya, 1984) 37-40.

24 Ibid., 40. 